\title{
The application of infraclavicular brachial plexus block with retroclavicular approach for arterio-venous fistula aneurysm
}

\author{
Arterio-venöz fistül anevrizması için retroklavikular yaklaşımla infraklavikular \\ brakiyal pleksus bloğun uygulaması
}

(1) Ömer KARACA, ๑ Hüseyin Ulaş PINAR

\begin{abstract}
Summary
Infraclavicular block provides adequate anesthesia to the arm, forearm, and antecubital region. There are many different approaches to infraclavicular brachial plexus block. Corocoid approach which is mostly preferred is not appropriate in some cases that needle orientation disappear. In this case report, we performed a newly defined retroclavicular approach to infraclavicular brachial plexus block and discussed in the light of information in literature. The patient who has 79 year old man, 29.36 body mass index, American Society of Anesthesiologists 3 with chronic renal failure was admitted to the operation room with complaint of aneurysmatic arteriovenous fistula in the left antecubital area. We planned the infraclavicular brachial plexus block with retroclavicular approach for better visibility of needle. The needle insertion point was posterior to the clavicle and the needle was advanced from cephalad to caudal. The block was effectuated after median nerve stimulation as the needle was advanced toward posterior of axillar artery. In our case with excess weight and life-threatening disease, it is highly reliable to perform infraclavicular block with retroclavicular approach indicated spread of local anesthetic, needle tip, and orientation without damage to nerve and vascular structures under ultrasound-guided.
\end{abstract}

Keywords: Fistula aneurysm; infraclavicular block; needle trauma; overweight; retroclavicular approach.

\begin{abstract}
Özet
İnfraklaviküler blok, kol, önkol ve antekubital bölgeye yeterli anestezi sağlamaktadır. İnfraklaviküler blok için farklı yaklaşımlar vardır. Bunlar içerisinde en sık olanı coracoid yaklaşımdır. Ancak iğne oryantasyonu her zaman mümkün olamadığı durumlarda coracoid yaklaşım uygun bir yaklaşım olmamaktadır. Biz bu olgu sunumumuzda, yeni tanımlanan retroklavikular yaklaşımı aşırı kilolu bir hastada uyguladık ve literatürdeki bilgiler ışığında tartıştık. Yetmiş dokuz yaşında, vücut kitle indeksi 29.36, ASA 3, kronik böbrek yetmezliği mevcut erkek hastanın sol antekubital bölgede arter-venöz fistul anevrizması için operasyon odasına alındı. Retroklavikular yaklaşımla infraklavikular brakiyal plexus bloğu planlandı. Ĭğne giriş yeri klavikulanın posterioruydu ve ultrason eşliğinde iğne cephalden kaudale, axiller arterin posterioruna doğru yönlendirilerek median sinir uyarılmasından sonra blok gerçeşleştirildi. Aşıı kilo ve yaşamı tehdit eden hastalığı bulunan olgumuzda sinir ve damar yapılarına hasar vermeden ultrason eşliğinde iğne ucunu, yönelimini ve lokal anestezik ajanın yayılımını görerek gerçekleştirilen infraklavikular bloğun retroklavikular yaklaşımla uygulanması oldukça güvenilirdir.
\end{abstract}

Anahtar sözcükler: Fistul anevrizması; infraklavikuler blok; iğne travması; aşırı kilo; retroklavikuler yaklaşım.

\section{Introduction}

Infraclavicular block is usually the regional anesthesia method of choice for surgeries involving the antecubital region and forearm. There are three most common approaches for infraclavicular block: Coracoid, lateral sagittal, and vertical. In addition, Charbonneau et al. ${ }^{[1]}$ described the retroclavicular approach to infraclavicular brachial plexus block in which block performing time was quick, safe and needle shaft and tip were visible. Herein, we report a retroclavicular approach to induce a successful infraclavicular brachial plexus block in a overweight patient.

\section{Case Report}

A written consent form was obtained from the patient for this case report. An ultrasonography-guided

Department of Anaesthesiology and Reanimation, Başkent University Faculty of Medicine, Konya, Turkey

Submitted: 21.03.2018 Accepted after revision: 12.11.2018 Available online date: 20.11.2018

Correspondence: Dr. Ömer Karaca. Başkent Üniversitesi Tıp Fakültesi, Anesteziyoloji ve Reanimasyon Anabilim Dalı, Konya, Turkey.

Phone: +90 - 530 - 1565776 e-mail: dromerkaraca@hotmail.com

(c) 2021 Turkish Society of Algology 


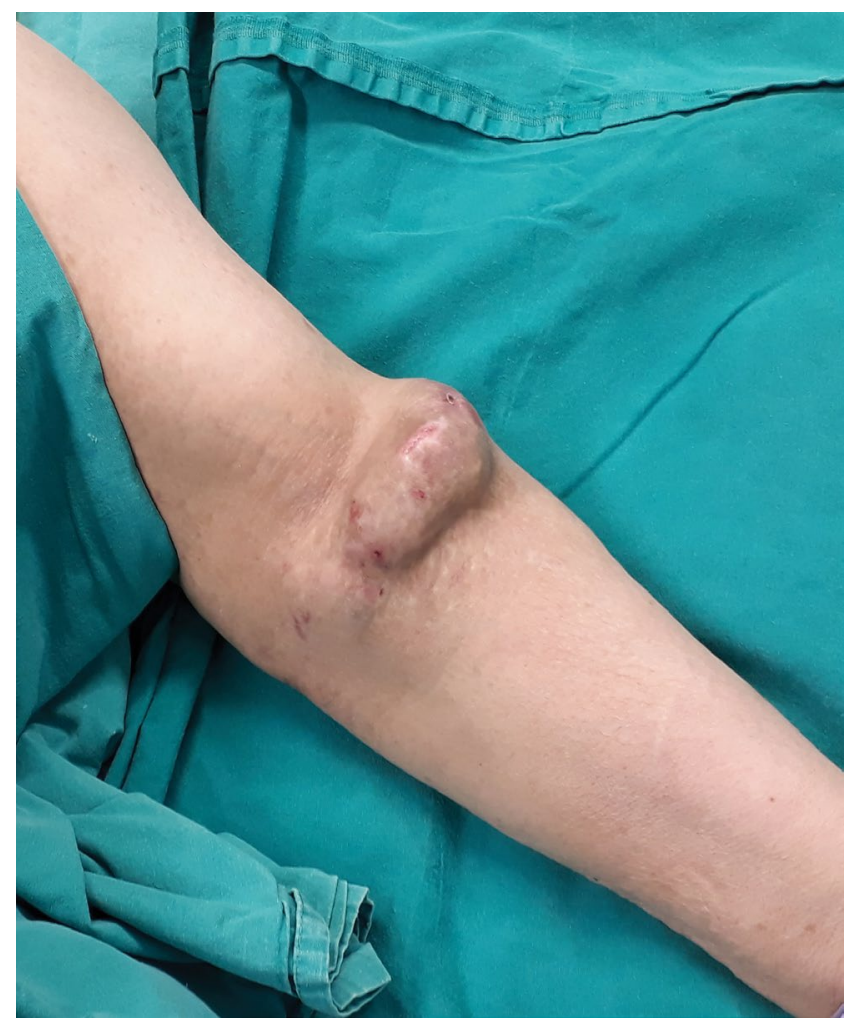

Figure 1. Arterio-venous fistula aneurysm in the antecubital region of the left arm.

infraclavicular block was scheduled to be performed before the operation of an aneurysmatic arteriovenous fistula in the left antecubital region (Fig. 1) created for chronic renal failure in a 79-year-old man with a height of $163 \mathrm{~cm}$, a weight of $78 \mathrm{~kg}$, and a body mass index of 29.36 .

In the operating room, the patient was placed in supine position, with his arm adducted and head rotated to contralateral side of the blockade. A $10 \mathrm{MHz}$ linear probe $(6-13 \mathrm{MHz}$, Sonosite, Bothell, WA, USA) with a sterile cover was placed parasagittally, just medial to the coracoid process and caudal from the clavicle (Fig. 2a). A 21-gauge $100 \mathrm{~mm}$ needle was inserted above the clavicle into the space between the coracoid process and the clavicle, and advanced from cephalad to caudal. After crossing the blind zone (clavicula shadow), needle was advanced toward the neurovascular bundle (Fig. 2b). $15 \mathrm{~mL} 0.25 \%$ bupivacaine was injected to 6-o'clock position of the axillary artery. Then, the needle was withdrawn to 7 o'clock position and $10 \mathrm{~mL} 0.25 \%$ bupivacaine was injected to ensure the coverage of the lateral cord. $5 \mathrm{~min}$ after performing the block, sensorial and motor blockade were observed in the left arm. The surgery lasted for $90 \mathrm{~min}$ and was completed uneventfully.
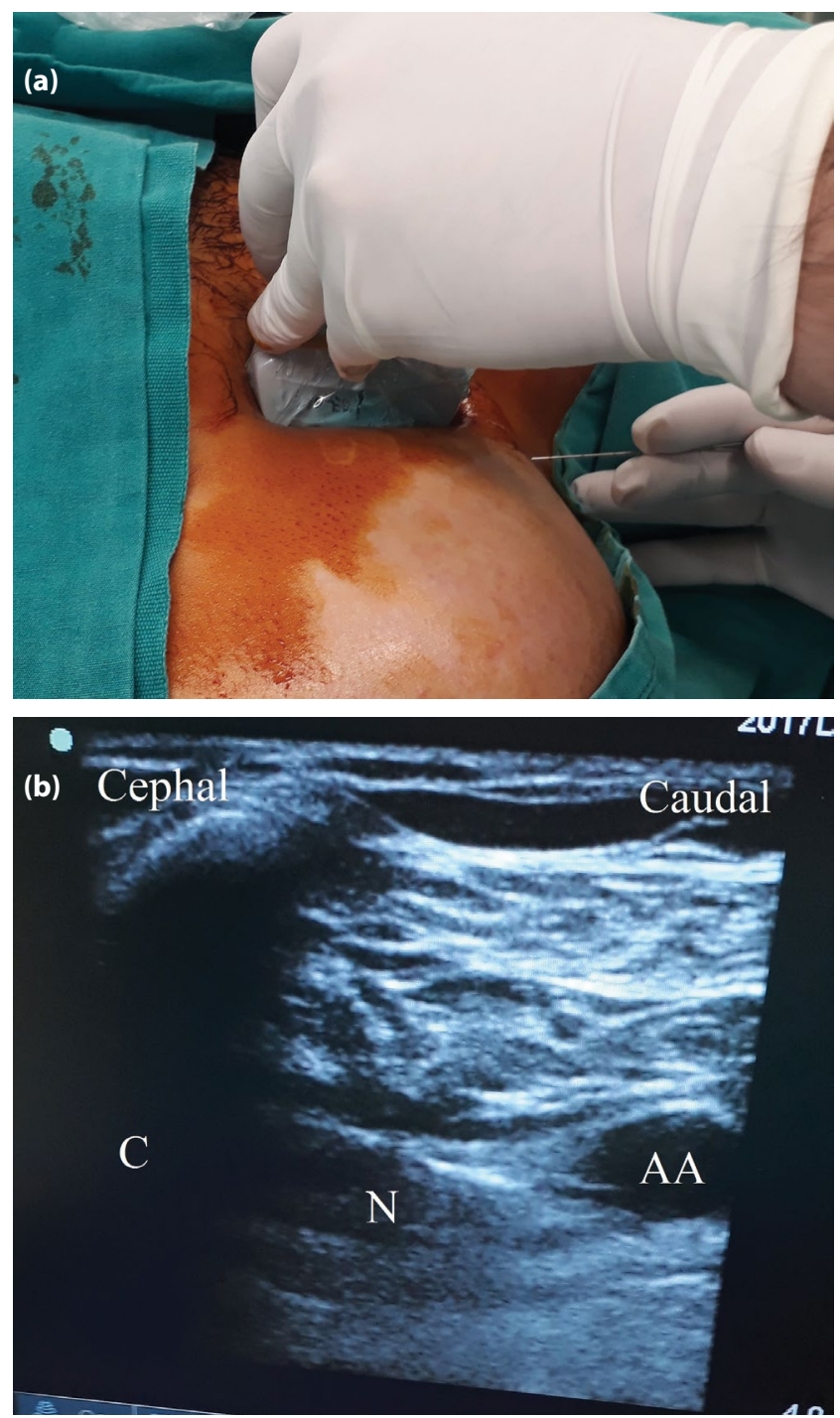

Figure 2. (a) Retroclavicular approach for ultrasound-guided infraclavicular brachial plexus block (Position of the transducer and block needle insertion point). (b) Ultrasound image demonstrating the needle pathway. The needle advanced cephal to caudal.

C: Clavicula, N: Needle, AA: Axillar artery

\section{Discussion}

As an excessive amount of subcutaneous fat tissue prevented us from distinguishing the locations of the needle and neurovascular structures while inducing an ultrasound-guided infraclavicular block using a coracoid approach, we preferred a retroclavicular approach for infraclavicular block to perform the block easily and avoid complications as view both the needle tip and shaft.

In the traditional coracoid approach to infraclavicular block, both the vascular structures such as acromial division of thoracoacromial artery and cephalic vein which lies between pectoralis major muscle and pectoralis minor muscle and lateral cord is al- 
most located at the cephalic anterior aspect of the axillary artery, which typically lies in the traditional infraclavicular block needle path are susceptible needle trauma. ${ }^{[2]}$

Soeding and Eizenberg ${ }^{[3]}$ reported that cephalic vein and acromial branch of the thoracoacromial artery can be exposed to the needle trauma when coracoid approach is performed, because of needle path. Besides, the percentage of paresthesia during performed coracoid approach was noticed as $17 \%$ by Frederiksen et al., ${ }^{[4]} 7.5 \%$ by Tran et al., ${ }^{[5]}$ and $12 \%$ by Ozturk and Kavakli. ${ }^{[6]}$

Charbonneau et al. ${ }^{[1]}$ indicated that retroclavicular approach to infraclavicular brachial plexus block was safe and quick, because needle shaft and tip were viewed better. Furthermore, through this technique, the needle is away from these neurovascular structures. ${ }^{[6]}$ Kavakli et al. ${ }^{[7]}$ reported that infraclavicular block with retroclavicular approach which needle orientation could be easily implemented in a patient with implanted pacemaker difficulted needle visibility in the left pectoral area.

Ozturk and Kavakli ${ }^{[6]}$ reported that the needle tip and shaft were more discernible and the duration of procedure shortened with the retroclavicular approach, as compared to the coracoid approach to infraclavicular brachial plexus block. A more perpendicular alignment of ultrasonic waves with the retroclavicular approach compared to the coracoid approach increases the visibility of the needle tip and shaft. Hence, we preferred retroclavicular approach for infraclavicular brachial plexus block to forestall both deteriorate to needle orientation and damage to neurovascular structures during coracoid approach.

Local anesthetic may not necessarily disseminate into the lateral cord while inducing infraclavicular block. Uppal et al. ${ }^{[8]}$ suggested a technique called as 5-6-7 in which $25 \%$ of the total amount of a local anesthetic should be injected to artery at 7 o'clock position for lateral cord coverage. We performed local anesthetic injection to both 6 o'clock and 7 o'clock positions while producing block.

We demonstrated that infraclavicular block is easily performed by obtaining a clear image of the needle, away from neurovascular structures, using the retroclavicular approach, for this overweight patient who had comorbid conditions.

Informed Consent: Written informed consent was
obtained from the patient for the publication of the
case report and the accompanying images.

Conflict-of-interest issues regarding the authorship or article: None declared.

\section{Peer-rewiew: Externally peer-reviewed.}

\section{References}

1. Charbonneau J, Fréchette Y, Sansoucy Y, Echave P. The ultrasound-guided retroclavicular block: A prospective feasibility study. Reg Anesth Pain Med 2015;40(5):605-9.

2. Sutton EM, Bullock WM, Gadsden J. The retroclavicular brachial plexus block: Additional advantages. Reg Anesth Pain Med 2015;40(6):733-4. [Crossref]

3. Soeding P, Eizenberg N. Review article: Anatomical considerations for ultrasound guidance for regional anesthesia of the neck and upper limb. Can J Anaesth 2009;56(7):51833. [Crossref]

4. Frederiksen BS, Koscielniak-Nielsen ZJ, Jacobsen RB, Rasmussen $\mathrm{H}$, Hesselbjerg L. Procedural pain of an ultrasoundguided brachial plexus block: A comparison of axillary and infraclavicular approaches. Acta Anaesthesiol Scand 2010;54(4):408-13. [Crossref]

5. Tran DQ, Russo G, Muñoz L, Zaouter C, Finlayson RJ. A prospective, randomized comparison between ultrasoundguided supraclavicular, infraclavicular, and axillary brachial plexus blocks. Reg Anesth Pain Med. 2009;34(4):366-71.

6. Ozturk NK, Kavakli AS. Comparison of the coracoid and retroclavicular approaches for ultrasound-guided infraclavicular brachial plexus block. J Anesth 2017;31(4):572-578.

7. Kavakli AS, Durmaz MT, Yilmaz ZY, Turhan S, Ozyurek L. Retroclavicular approach to infraclavicular brachial plexus block for distal radius fracture in a patient with implanted pacemaker. J Clin Anesth 2018;44:76-7. [Crossref]

8. Uppal V, Kalagara HK, Sondekoppam RV. Tips and tricks to improve the safety of the retroclavicular brachial plexus block. Am J Emerg Med 2018;36(6):1107-8. [Crossref] 